\title{
Risks Faced by Independent Colleges and Management Countermeasures
}

\author{
Ding-xiang LIU, Ai-qun YU* and Tao LI \\ City College of Science and Technology, Chongqing University, Chongqing, China \\ ${ }^{*}$ Corresponding author
}

Keywords: Management of the Risk; Independent Colleges; Policy Risk.

\begin{abstract}
As a kind of emerging organization in the process of China's high education reform, independent colleges face many risks in the establishment and development. This article focuses on the analysis of the policy risks faced by independent colleges and analyzes the policy features including uncertainty, asset transfer, imperfect supporting policies, and the passivity of the policies. Corresponding countermeasures to the risks were also suggested.
\end{abstract}

\section{Introduction}

Independent colleges refer to colleges and universities that carry out undergraduate education or higher and social organizations or individuals other than state agencies. Colleges and universities carrying out undergraduate education with non-state financial funds are one of the emerging types of higher education reform in China. The new mode of running a school is a new exploration in running mode of higher education. In the course of exploration, the relevant decision-making departments of the State pay attention to the research norms and issue relevant opinions and systems according to their development.

\section{The Characteristics of Independent College}

An independent college as a new organizational model is different from the traditional secondary teaching units in public colleges and universities, and different from private schools which are simply organized by social forces. Independent colleges combine the qualities of colleges and enterprises. In some cases, the quality of teaching conflicts with the interests of enterprises. Therefore, with its flexible and free form, Independent College has injected fresh vitality into the higher education in our country and at the same time, it has also put forward new topics for teaching management.

Independent colleges have the following characteristics:

a. Five independent. That is, have an independent campus and basic facilities for running schools; can implement relatively independent teaching organization and management; independent enrollment, diploma awarded; independent financial accounting; external can bear civil liability independently. The relationship between independent colleges and universities is not an administrative subordinate relationship, but an equal civil subject relationship.

b. The independent college is the product of cooperation between colleges and social forces, both involved in investment. In other words, independent colleges have both public and private components. Social forces are invested, colleges and universities invested in the school headquarters of intelligence, human resources and management experience and other intangible assets.

\section{The Policy Risks Faced by Independent Colleges}

Independent college policy risk refers to the government or higher education administrative departments for independent college policy changes or important initiatives, the introduction of laws and regulations, may lead to fluctuations in the operation of independent colleges, resulting in the risk to the development of independent colleges. 
As a newcomer to the development of higher education, in the initial stage of the development of independent colleges, the attitude of the government is protection and encouragement. The independent colleges have fewer regulations and the laws and regulations are rather imperfect. Moreover, there are many different organizers of independent colleges, leading to many difficulties facing independent colleges. Some education experts have pointed out: Independent colleges have the name of public universities, less public universities; funding channels for private universities, lack of supervision mechanism for private universities. In this sense, an independent college is like a "freak." An independent college is a new organizational model, and many new problems in management are inevitable.

\subsection{Policy provisions in the transfer of assets risk}

Article 12 of Decree No.26 of the Ministry of Education in 2008 stipulated that the capital contribution of the sponsor of an independent college shall be capitalized according to law and be transferred to the name of an independent college during the preparation period. In 2016, "Several Opinions on Encouraging Social Forces to Build Education and Promote the Healthy Development of Private Education" stipulated that during the period of existence, private schools would like to hold the assets of the school, state-owned assets, donated property, Organizations and individuals shall not occupy, misappropriate, and flee. This means that once an investor transfers an asset to an independent college, the property belongs to an independent college and has nothing to do with it, and so the investment has in effect become a donation and, in accordance with the Ministry of Education's request for transfer of assets, Transfer procedures is the investor, the transfer of various taxes involved in the process should also be borne by the investor, which undoubtedly increased the risk of investors.

\subsection{Related supporting policies are not perfect}

The promulgation of Decree No.26 of the Ministry of Education clarified the relationship of property rights and promoted the independent college to truly run the school under the name of an independent legal person. It eliminated the frequent contradictions and risks between the two parties during the running of the school, solved the issue of independent colleges and ensured the steady running of the school Enhance. However, how to implement and realize the goal of Decree No. 26, there are still lack of practical and specific policies and supporting measures. For example: how to carry out policy support for independent colleges, how to evaluate the quality of running an independent college, and how to design a guideline supporting policy for independent college teachers.

Ministry of Education Decree No. 26 stipulates that after independent college is completely independent, it is necessary to further improve the quality of teaching. When the conditions are ripe, it will receive the education evaluation of education authorities and set up a quality assessment system suitable for such institutions as independent colleges so that Independent Colleges like public undergraduate colleges and universities to accept the Ministry of Education assessment, and through the assessment, rectification or elimination of substandard institutions. However, whether independent colleges adopt the same quality assessment system as that of public undergraduate colleges or reestablish a quality assessment system based on the actual conditions of independent colleges and the positioning of running schools becomes a major issue concerning the existence of independent colleges. At present, the relatively large risk is that the standards adopted by independent colleges for the quality assessment of running schools have not yet been determined. If the two standards of "Interim Provisions on the Establishment of Regular Undergraduate Schools" and "Criteria for Basic Running Conditions of Colleges and Universities for Higher Education (Trial)" are required by the Ministry of Education Independent colleges, the standard is obviously too high, most independent colleges are probably not up to standard. In fact, these two standards were put forward in the elite stage of higher education. In the process of the previous university quality assessment, even though there are many public colleges and universities, they can barely be qualified only by means of temporary assault or even fraud. At present, China's higher education has entered the stage of popularization and is moving toward the stage of popularization. 


\subsection{The risk of policy uncertainty}

There are two manifestations of the indecisive impact on the policy of independent institutes reverse policy risk and sudden policy risk. The former refers to the risks arising from the discrepancy between the orientation of policies and the inherent development direction of independent institutes in a certain period of time. This risk is magnified when the operating conditions of an independent college are incompatible with the adjustment policies of the higher education authorities. For example, independent colleges hope to increase their tuition fees according to their own cost operation. If the education authorities issue restrictive policies and regulations in a targeted way, they may result in the failure of independent colleges to increase their tuition fees. Catastrophe policy risk refers to the risk posed to the development of an independent college due to a sudden change in the policy dimensions of the educational authorities. For example, when the Independent Institute was established in 1999, the state did not ask for the transfer of assets to be completed as an independent college legal personality when it encouraged the social capital to actively invest in establishing an independent college. However, in the 2008 Decree No. 26 , it was suddenly proposed Requirements, and implemented a new policy that cannot be checked through inspection by the Ministry of Education without completing the transfer of assets. Although this sudden policy adjustment was intended to promote the healthy development of independent institutes, its departure from the objective of pursuing economic benefits by some of the social capital that was used to set up independent institutes in advance, resulting in the temporary inability of these enterprises to adapt and even led to the withdrawal of some private capital or Transfer funds to withdraw.

Under the new policies in November and December 2016, privately-run colleges and universities can choose between for-profit schools and non-profit schools. In the new policy, "private colleges and universities enjoy preferential tax policies prescribed by the state," but emphasized that "among them, non-profit private colleges and universities enjoy the same preferential tax policies and public schools," as for how profitable private colleges enjoy preferential policies No specific instructions. In addition, the school land to implement differentiation policy, according to the policy: "New expansion of profit-making private schools, the people's government shall provide land in accordance with state regulations." For-profit private universities and non-profit private colleges and universities, less "land Preferential ", virtually increase the survival pressure for profit-making private colleges and universities.

\subsection{The passive risk of the policy}

An independent college is essentially a new-born thing with a clear nature of experimental exploration. Policies toward independent colleges are often introduced only afterwards, and lack of vision and leadership. The development of independent colleges lacks a precise positioning in the higher education system for more than 10 years. The Law of the People's Republic of China on Promoting Private Education does not make any clear explanations on such issues as reasonable returns. The development of independent colleges has always been rather awkward. Owing to the uncertainty and lag of policies, there is a lack of normative constraints on the participants of Independent Colleges and it is easy for them to behave in different ways. As a result, many Independent Colleges have contradictions. For example, after paying a certain percentage of tuition fees as a management fee, the parent universities are not very concerned about the costs and benefits. Investors pay more attention to the costs and benefits of running a school. However, the two sides are controversial over the remaining control. Due to the lack of relevant policies, there is no policy basis for the actions of both side, As a result, both sides disagreed with each other. It led to even intensify the contradictions, thereby affecting the continued running of schools.

If we can't improve the independent rights of independent legal entities in institutions and improve the internal organizational structure and perfecting the daily rules and regulations of running schools, we can only make them compete in a disorderly environment out of the rules of higher education development and simply based on Market rules to run, then, independent college can become independent, can be independent, its prospects are not optimistic. 


\section{Management of the Risks}

Numerous examples show that establishing a scientific concept of risk management is more important than identifying and assessing risks. Many independent colleges have been rectified or suspended due to risk control problems. The reason is that the lack of risk control mechanism in independent colleges is due to the fact that the awareness of risk management in independent colleges is too weak.

\subsection{To establish the risk management system}

Independent colleges to implement a comprehensive risk management, the top-level design needs to be done, we should establish and improve the management system as soon as possible. We will improve the system of risk management, learn and publicize the spirit of relevant laws and regulations, and administer schools in accordance with the law. We will redouble the risk management by complementing and improving the risk management system so as to reduce duplication and conflicts among departments and prevent the spread of risks. In addition, we should also improve the management mode and strengthen the internal coordination and information communication of various factors in management. In the process of formulating the risk management system, the departments should be strengthened to clarify the responsibilities of various departments. This will not only reduce the blindness of policy formulation, But also get the understanding and support of the executive department of the system to reduce the resistance during the implementation of the system.

\subsection{To develop contingency plans for risk events}

In order to prevent similar risk situations from expanding, independent institutes should establish the necessary contingency plans rather than rush to deal with them, causing the crisis to get out of control. For example, independent college teachers have a high rate of job-hopping, and individual teachers suddenly quit without giving any advice. As a result, the entire arrangement of relevant professional student courses was disrupted completely. In response to such problems, the College can take contingency plans include: All courses, especially the professional backbone courses, must be at least two or more teachers to open, must not be the case of a teacher with only one course, and requires that every one Teachers should have at least 2 different courses offered. Teachers should also take the approach of establishing a pool of talented teachers so that someone can be on top any time they need it.

\subsection{Enhance leadership and execution}

The building of leadership and executive capacity in independent college management is important because they are the key to reform and development of schools and to comprehensive risk management. The leaders, organizers and promoters of education are the key and core to ensure the coordination and operation of all departments of the school. The management leadership is directly related to whether the teaching, research and management of the college can be successfully completed. In order to enhance the level of leadership and execution of management, management should take the initiative to participate in training and learning. Through regular risk education, especially management's legal knowledge, risk prevention knowledge, risk management knowledge and actual risk case analysis, improve management's ability to respond to risks.

\subsection{Improve the quality of education}

Reform the curriculum system, strengthen teachers' ability and strengthen practical teaching. On the basis of this, we make use of the prestige, influence and brand superiority of the parent universities in the society, insist on implementing the strategy of teaching quality improvement, establish and improve the monitoring system of teaching quality, Compression epitaxial development space, take the road of connotation development. We should put more emphasis on teaching quality, connotation, and sustainable development instead of previous attention to school scale, extension, and hot majors. 
The establishment of an independent college should be based on full respect for the rules of higher education on the basis of the initiative to adapt to the market of new talent. Needs, on the one hand to play the professional advantages of the existing disciplines of the school, to create a brand of specialty, cultivate specialty; on the other hand to explore or cultivate new professional through the market. Optimize the professional settings to focus on job-oriented and market demand, professional construction should proceed from its own comparative advantages, professional settings have long-term vision.

\section{References}

[1] JIANG Da-wu. The Ten-year "Independent" Way of Independent Colleges in China [J]. Modern Science of Education, 2009, No. 4 (41).

[2] WU Hai-liang.Analysis on Cultivation Mode of Applied Talents in Independent Colleges [J]. Journal of Yangtze University (Social Science), 2010 (05).

[3] Wu Rongshun, Gong Zhaojun, On the internal governance mechanism of our independent college problems and countermeasures - mirroring the American private colleges and universities comparative study [J]. Private Higher Education Research, December 2010 Volume 7, Article 4 period.

[4] He Weifeng. Business Risk Analysis and Risk Management of Private Independent Colleges [J]. Modern Economic Information, 2013 (5).

[5] Guo Weiguang, Fan Chunshu. The Evolution, Latest Development and Motivation of Risk Management in Private Universities [J]. Journal of Changchun Institute of Technology (Higher Education Research) Volume 35, Number 3, September 2014.

[6] Independent College Setup and Management Measures (Ministry of Education Decree No. 26) 2008.

[7] Private Education Promotion Law Enforcement Regulations, 2004. 